\title{
STRENGTHENING VOCAL REGISTER THROUGH TEMBANG JAWA ORNAMENT PRACTICE
}

\author{
Diah Latifah \\ Department of Music Education, Indonesia University of Education, Indonesia \\ E-mail: diah.singer@gmail.com
}

Received: November 15, 2015. Revised: November 30, 2015. Accepted: December 4, 2015

\begin{abstract}
This study analyzes Javanese's song ornament luk to strengthen vocal register. The movement of luk is either upward or downward has similarity to western vocal technique portamento. Portamento ornament is usually used in strengthening the switching technique of vocal register. Register is a vocal technique that has an advantage in maintaining timbre, so that the timbre sounds homogenous when the changing of register occurs. The results of the study show that the Javanese's song ornament Luke has successfully strengthened the vocal register on the practice of register intensification in western vocal disciplines.
\end{abstract}

Keywords: luk; vocal register intensification

How to Cite: Latifah, D. (2015). Strengthening Vocal Register Trough Tembang Jawa Ornament Practice. Harmonia: Journal of Arts Research and Education, 15(2), 113-118 doi:http:/ / dx.doi.org/10.15294/ harmonia.v15i2.4428

\section{INTRODUCTION}

This study is composed based on a specific background of experience. Specifically, the idea of this study is initiated when two students of music education program at Indonesia University of Education (UPI) are using Javanese's song ornament while attending western vocal instrument course. During the process, it was resulted that the technique used by the students were effective and able to strengthen their vocal technique. This phenomenon was then followed up by conducting research that might put variety of ornament in Nusantara together in order to strengthen students' western vocal technique.

Tembang Jawa or Javanese song is one of vocal arts in Javanese culture. The position of tembang in Javanese culture is depicted in the picture of Javanese's life. Tembang Jawa, especially mocopat (Javanese traditional song), is composed from stanzas in pupuh or Javanese ancient poem pattern. Kunst (1973, p. 122) states that "to the Javanese, singing and poetry are one in the same thing; poems are always recited in the song form". In other words, it means that for Javanese people, songs and poems are a form of unification, that a poem is always recited in a form of song. Tembang Jawa, specifically Mocopat, is categorized into sekar alit. It has a special ornament that beautifies the melody of its song pattern. Kusnadi (2011) argues that "The aesthetic strength of a tembang is placed on its literature and song ornament". Here, in tembang Jawa, one of the ornaments beautifying the song is Luk. Kusnadi (2011) states that "luk is two or more notes that are sung in one syllable, or in other words, luk is the arch or voice. The tone, direction of Luke is varied. Some are upward, downward, and others are upward, then downward and back to its initial position." Apart from luk is gregel that has a more complex ornament form. Gregel is 
considered as a combination between several luk ornaments that moves upward to downward and is usually fast. According to Kusnadi (2011), "gregel is a combination between several luks that are sung fast and hard to be denoted". Interview results with Prof. Suwardi on $31^{\text {st }}$ May 2015 found that "the ornament movement of gregel is more twisted and flicker". The movement of luk, that is twisted upward (high) or downward (low) has similarity with the ornament of western vocal that is termed by the name of Portamento. Pilotty (2009) in his thesis argues that:

should be used "sparingly for expressive purposes" (Stark 1999 p 165). In bel canto,portamento plays such an important role that it has become completely associated with the style. However, it is not only a decoration, but a means to maintain the position ('open throat') throughout the vocal range. This gives an unbroken feeling of legato and a homogenous timbre (interview with Nordfors).

Paparone in Milyartini, Latifah dan Virgan (2015) states that "In Italian Por- ta means bring and armento means the art of Portamento is the art of bringing one note to the next. The first note shifts gracefully to the next". The notation of Portamento can be seen in the following:

The vocal ornament as can be seen above is theoretically able to strengthen the register technique as delivered by $\mathrm{Pi}$ lotty.

There are three main categories of register according to Ploog (2004, p. 109). He argues that "the 3-register voice building approach aims at a homogeneous and balanced vocalization by mixing the voices during the passaggios". The position of high register, middle register, and low register as vocal technique can be seen from the following figure:

The register distribution for soprano and tenor is clearly seen from the figure above. The line of tone that forms a straight line to the chest belong to the low register. Meanwhile, for the point line that forms a straight line from the area above the mouth up to the forehead considered as middle register, and six tones placed at
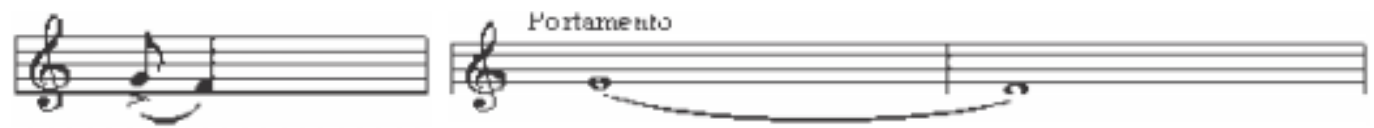

Figure 1. Paparone (2006) in Milyartini, Latifah dan Virgan (2015)

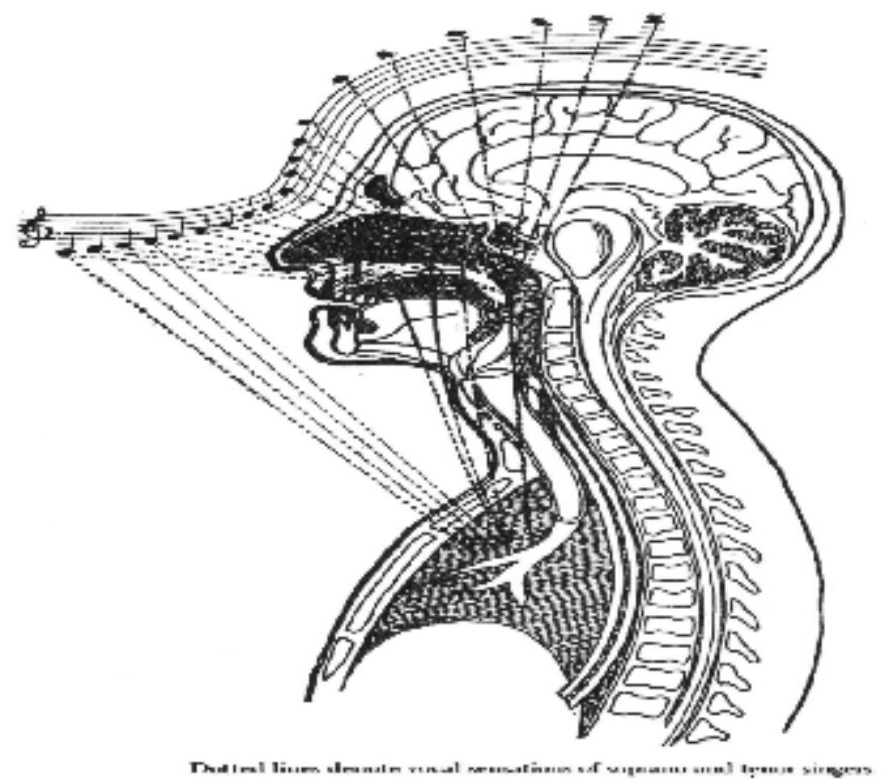

Figure 2. The sensation of voice register for Soprano and Tenor.

Source: Lehman. (1993, p. 44) 
the head categorized as high register.

The existence of the ornament of $l u k$ that has similarity to portamento ornament will be analyzed here in order to strengthen the register technique. Therefore, te problem arised in this study is whether or not the ornament of Javanese song (tembang Jawa) that is luk has an advantage in strengthening register. In other words, this study aims at observing the advantage of Javanese ornament, luk, to strengthen vocal register.

\section{METHOD}

\section{Approach and Method of the Research}

A research approach that is implemented in this study is monodiscipline art research. Steps of the research can be seen from the following figure 3 .

Research method implemented in this study was narrative inquiry and narrative explanation in a form of investigation. Data collected from the existed phenomena, as well as explanation from variety of findings related to the emergence of vocal technique register mastery that was shown when ornament luk on the etude that was created by researcher was sung by the research subject. The etude itself was having the characteristic of Javanese song.

Five third semester students of Western Vocal Instrument 2 course of the mu- sic education department of Indonesia University of Education became the research subject of this study.

\section{RESEARCH RESULTS AND DISCUS- SIONS}

\section{Data Description}

The research of Luke had strengthened the vocal register as experienced by five students of western vocal instrument 2 as respondents in this study. Details of the result are described, as follows:

For student number one (respondent 1) that had the low timbre or bass type of voice, had the register technique to occur from the middle to the high register. This student felt anxious when the register shift occurred, and asked for the instructor to repeat the etude he sang until the student (respondent 1) felt comfortable and flexible in singing the tone. Eventhough the students had been able and flexible in singing the tone up in the high register, however, there were times when the student had difficulties in singing the tones during the register shifting. Here, he experienced out of register, sound off, and mispositioned. After doing the practice twice with the instructor guidance, the student provenly could achieve the high register well eventhough the student's voice production was still less sonor or round.

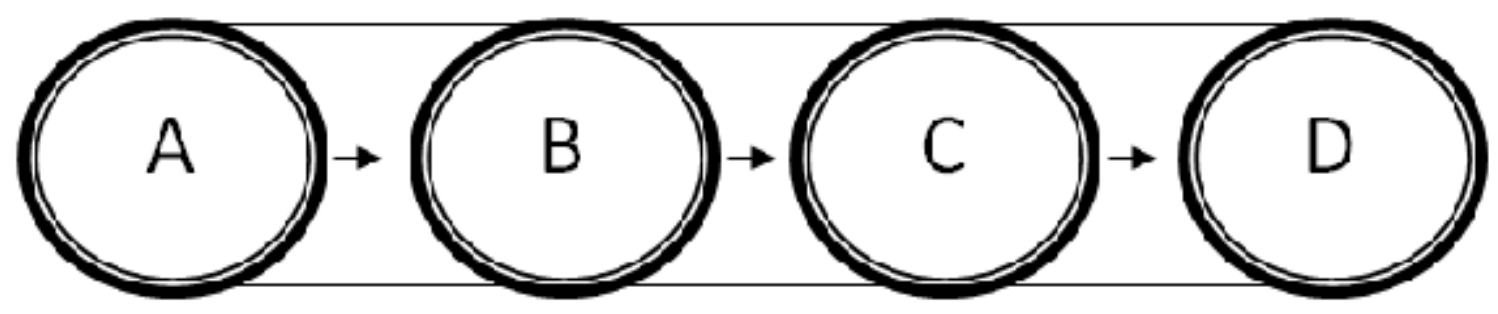

Figure 3. Rohidi (2011, p. 63) Monodiscipliner Approach

Note:

A: Vocal disciplines

B: Vocal technique theory focusing on vocal ornament of both western tradition and Javenese song in luk ornament

C: Narrative Inquiry and Narrative Explanation research method

D: Problem (Ontological Facts) on the indication of tendency on the emergence of the mastery of vocal technique register through the implementation of ornament luk on Javanese song 
Student number two (respondent 2) with limited breathing management found difficulties while maintaining his register technique. In the level of middle register, tension was found, and out of register happened several times. All tensions in sound production that were sung with limited breathing techniques, produced rigid and less flexible sound since there was muscle tension around the neck. It was due to the lack of breath that might support the voice to run high up to the position head voice. After repeating the song several times with the instructor's guidance, this student was finally able to accomplish the etude and the register technique flexibly. However, still, the best result of the student was still in the middle register. Both high register and head voice were slightly accomplished.

Student number 3 (respondent 3) constrained in the detention of voice, due to the limited breath support that was by all means needed to continue the long phrase. With the limited breathing technique management, it affected the register management technique of this respondent. Sometimes, register shifting went well both in the low and middle register position. However, for this student, out of register phenomenon was occurred when the voice position was actually still in register position, and was separated from the position of head voice. The position of head voice had been achieved after six times practicing etude eventhough the voice was still full of tension and resulted to thin voice production.

Student number four (respondent four) had enough ability in maintaining register only when he positioned the voice in head voice (high register) through register technique management. There was tension during the practice and the position of head voice was finally accomplished with a thin production quality and tended to produce when the register was positioned in the middle. This student also produced nasal placement several times. After trying to practice for several times, this student made some improvements. The instructor had been successfully guiding the respondent to the head voice position and achieved the high register well, eventhough, the voice production had not been fully sonor or round.

Student number five (respondent 5) experienced obstruction in producing the tone stability. Breathing technique had been mastered by the respondent even when it was the first time he practiced. However, while producing $l u k$, breath detention was hard to be produced because of the music's slow tempo. The middle register mountain and head voice were accomplished, but, stability was hard to be achieved due to the lack of stabil tone production.

\section{Discussion}

The results of the study show that Javanese song ornament Luke has a power to build up the technique register on vocal practice. Register technique can be achieved by all five respondents, even though, to achieve fully head voice and around donor has not achieved perfection. High register has been mastered by four students well. Meanwhile, one student (respondent number three) still produced high register sound with strain. Therefore, respondent number three still considerably needs an attempt to practice for three more times until voice stability and high register are achieved.

The strengthening register for several respondents that have limited vocal technique was not perfect enough due to the lack of respondent's awareness to maintain the register shifting technique. When the respondent produced luk in interval area, from the middle into high register, generally, middle to high register shifting was occurred. During the process, respondents usually experiences inadvertence. The inadvertence was shown when respondents were usually not ready to maintain their breathing technique or lack in supporting breath power while luk was sung and the register shifting occurred. As a result, it became the main cause of register technique imperfection. 


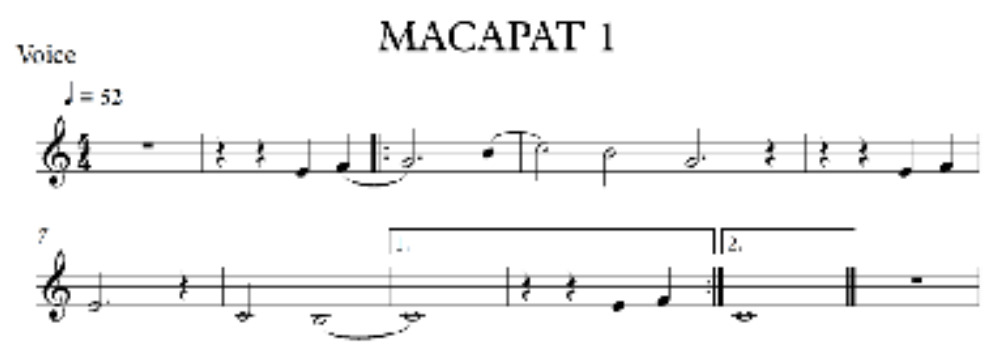

Figure 4. Partitur etude number 1 composed by researcher

The voice type of five respondents are bass, alto, and mezzosopran. The register shifting is different for each respondent. It depends strongly on voice range of every individual. Therefore, bass, alto, and mezzosopran singer will have different register shifting as well.

In general, all respondents had strengthen their register technique. In general, the movement of the best register achievement is placed in low and middle register, and the register movement moves from chest up to the forehead. Further, eventhough the high register has been achieved, however, the voice quality is not fully round with proper volume or sooner. One of the students, even though he had been able to achieve the high register, however, the voice was usually less stable.

Further, respondent number one to five experienced problems in middle to high register, as can be seen from the following scores.

The problem occurred when the voice moved from tone $b^{\prime}$ to see", as illustrated in bar shifting three to four. Besides the register shifting, the etude tempo is considerably slow. Therefore, tension is frequently occurred if the breathing technique is not ready to support the movement of upward luk (luk tangi) as written in Figure 4.

\section{CONCLUSION}

Research results and discussion show that the practice of singing luk ornament has proven to be effective in strengthening the vocal register. It is due to the character of luk ornament, that has the western vocal ornament character portamento, presents a smoother extreme interval voice. This happened because of the interval leaps from one tone to another town with a swing of the voice stream. This performance will eliminate tension of the sound production. The activity of register strengthening vocal will be achieved well if the breath power can be used by the vocalist well. The sound production process as explained above is proven to be successfully produce a good vocal register management technique. The changing of timbre happened along with the register shifting. This is not considerably pronounced, however, it seems to be blended and produces the same timbre.

\section{REFERENCES}

Budiarti, M. (2003). Konsep Kepesindenan dan Elemen-elemen Dasarnya. Harmonia Journal of Arts Research and Education, 13(2), 147-156.

Kusnadi. (2011). Tembang dalam Pertunjukan Langen Mandra Wanara. Imaji. $9(2), 11-28$

Kunst. J. (1973). Music In Java. Netherlands: Martinus Nijhoff

Lehman, L. (1993). How To Sing. New York: Dover Publication

Milyartini, L., \& Virgan. (2015). Model Pembelajaran Teknik Vokal Berbasis Ragam Ornamentasi Vokal Nusantara. Research Report. Bandung: Universitas Pendidikan Indonesia.

Pilotti, K. (2009). "The Road To Bell Canto". Document collection: UPPSATS, 2009:2 Musicology with Artistic Focus. Thesis. Sweden: Örebro University.

Ploog, K. (2004). Voice Coaching. Bonn: 
Voggenreiter

Pranoto, H.S. (2013). Sacrilegious Aspect of Javanese Gamelan: Past and Future. Harmonia: Journal of Arts Research and Education, 13(1), 55-68.

Rohidi, T. R. (2011). Metodologi Penelitian Seni. Semarang: Cipta Prima Nusantara
Widodo, B.S. (2000) Slendro Pelog: Suatu Keterasingan di Dunia Anak. Harmonia Journal of Arts Research And Education, 13 (1), 30-38.

Widodo, B.S. (2006). Nuansa Laras Diatonik dalam Macapat Semarangan. Harmonia Journal of Arts Research and Education, 7(1), 41-49. 